\title{
A STUDY OF PSYCHOLOGICAL CONFLICT AS A LESBIAN IN ANNIE ON MY MIND NOVEL BY NANCY GARDEN
}

\author{
Sella Damayanti (Corresponding Author) \\ Letters Faculty, Kanjuruhan University of Malang \\ Jl. S. Supriyadi 48 Malang 65148, East Java, Indonesia \\ Phone: (+62) $85707646424 \quad$ E-mail: sheelut@ymail.com
}

Mujiono

Letters Faculty, Kanjuruhan University of Malang

J1. S. Supriyadi 48 Malang 65148, East Java, Indonesia

Phone: (+62) 341-801-488_Ｅ-mail: moejie_nova73@yahoo.com

\begin{abstract}
In life, there are so many problems. Problems also happen in novel. We find various kinds of problems in novel which reflect the main characters' daily life. The problems are sometimes in the form of psychological conflict. this kind of conflict is harder to solve especially for minority people such as lesbian. It is interesting to study about psychological conflict in novel, especially in Nancy Garden novel entitled Annie On My Mind. The novel is about Liza Winthrop as the main character faces her problem as a lesbian. This novel also was banned and burnt because Nancy garden was the first author for young adults to create a lesbian love story. Therefore, the researcher has been interested in studying this problem by formulating three research problems such as: (1) How is psychological background of Liza Winthrop as the main character in Annie On My Mind novel by Nancy Garden? (2) What are psychological conflicts that Liza Winthrop got when she realized that she fall in love with Annie Kenyon in Annie On My Mind novel by Nancy Garden? (3) How Liza Winthrop character in the Annie On My Mind novel by Nancy Garden overcomes her psychological conflict? The research design which used in this research is descriptive qualitative research since the researcher intends to describe psychological backgorund, psychological conflict, and the way overcome the conflict. The data in this research analyzed into six steps, i.e data collection, data analysis, data reduction, data display, conclusion drawing, and data reportation. The researcher found there are five of Liza's Winthrop character or psychological background that is formed based on her life environment. Those are introvert, masculin, responsible, idealis, and kind-heart person. Those Liza Winthrop's psychological background influence
\end{abstract}


Liza in overcome her psychological conflict which there are two of the most of psychological conflict faced by her, they are approach-approach conflict and double approach-avoidance conflict. Finally, the researcher really hopes for the student to learn fiction deeply and enjoyed analyzing literary works. And for the lecturer in English Literature Department, lecturer can give explanation about analyzing another aspect in the literary works in order students will not bored in learning or studying fiction. Last, but not least, for the further researcher, they could take different way in analyzing the literary works.

Keywords: Psychological conflict, psychological, character 


\section{Introduction}

Every human in this world certainly have problems. Their problem can come from anywhere. For example, problem with personality. Self conflict is a thing that always happen in human beings. Feel confidentless, feel having multiple personalities, or even feel something abnormal in their self.

Feeling abnormal is one of the biggest inner conflict in human life. Some of them feel that will be alright, but others will feel distress. For instance, a woman who has feeling to woman, or we common called her as a lesbian or homosexual.This thing will be really complex if the woman live surrounded by people who think it as a taboo. Sexual minority women are at higher risk of despression and anxiety. They, especially youth who identify themselves as lesbian have a higher risk of despression and attempted suicide. It is because of social alienation, discrimination, rejection by loved ones, abuse, and violence. The problem might be more worse when they lack of social support.

From the reality that occur in this life, many characters in a novel literary take many kind of conflicts from problem in this life. The conflict is the basis for everything else included in the literary work. Conflict usually creates tension and interest in the story by adding doubt as to the outcome and a person who reads the story usually want to see how a conflict is developed and then resolved.
As researcher explained before, every human in this world certainly have problems. It is also like in the novel, every human beings has the experiences to face conflict in their life. Every conflicts that human beings have in their life, they will find out the way to solve it. Conflict also has close relationship with human psychological. It can influence human psychological.

Psychological conflict in human character is one of kind of conflict that usually find in a novel literary. According to the encyclopedia Britanica, conflict, in psychology, the arousal of two or more strong motives that cannot be solved together. As well as a youth who experience a conflict between two desired satisfications that has to choose between two attractive and practicable careers, may lead him to some vacillation. Psychological conflict is a man struggling against himself, his conscience, his guilty, or simply trying to decide what he is going to do (Jones in Astiningsih, 2005 : 12).

Lesbian is one of character in a novel literary. Wikipedia state that a lesbian is a female homosexual ; a female who experiences romantic love or sexual attraction to other females. Andhiaty (2007), lesbian is a woman who has an emotional erotic and sexual emotion, especially with women or who see herself particularly with women who identifies herself in a lesbian community.

Psychological conflict as a lesbian can be a serious thing that usually find in a real life or in the novel. They are must be face difficulties in the society life which is most 
of them admire that lesbian is not good, problem, and abnormal thing. So they will ignore lesbian couple, or the worse thing that they will get is isolation from society.

The fact that become lesbian means become trouble maker is proven by Nancy Garden's novel. Annie on my mind novel by Nancy Garden that was published by Farrar, Straus, and Girout in 1982, the novel with genre young adult, romance, and lesbian. The novel is one of the most challenged and banned novel. As an author, Nancy Garden have to face her best known work was banned by the Kansas City school system and burnt in demonstration in 1993 just because the novel arrise lesbian character which at the time many parents objected. Fortunately, the novel was returned to shelves only after a first amendement lawsuit by student in 1995 and also continues to be printed, checked out of libraries, and stocked on bookstore shelves more than three decades later after its publication.

In this novel, there are two main characters, it's Liza Winthrop and Annie Kenyon. They are in the same old 17 and the two become fast friends, although they come from different background. When two of Liza's female teachers (who live together) go on vacation during spring break, she volunteers for the job of taking care of their home and feeding their cats. The two girls stay at the house together, but in an unexpected turn of events a Foster Academy administrator discovers Liza and Annie together. Liza is forced to tell her family about her relationship with Annie, and the headmistress of her school organizes a meeting of the school's board of trustees in order to expel Liza.
By the explanation above, the researcher want toanalyze Nancy Garden's novel entitled "Annie On My Mind" for some reasons. First is the researcher want to study more about the problems in the novel, especially about psychological conflict that faced by Liza Winthrop and Annie Kenyon as a lesbian couple.Second, there are some conflicts in this novel which is influenced the lesbian character psychological. The way the author expresses the problem is also very entertaining. Third, researcher find the fascinating things with the novel itself. However the novel was banned and burnt, Nancy Garden as a author won the annual award in 2003 when the panel cited Annie On My Mind alone and called her "the first author for young adults to create a lesbian love story with a positive ending. Using a fluid, readable style, Garden opens a window through which readers can find courage to be themselves." Not only that, Annie On My Mind also was awarded the Lee Lynch Classic Award by the Golden Crown Literary Society in 2014, cited as one of the most important classics in lesbian literature. However the reasons above, in this study, the researcher tries to stay focus onthe psychological conflict of the lesbian character of the novel. The novel provides much information to be analyzed. Such as analyzing the psychological conflict faced by the character on the novel. Therefore, the researcher conduct an analysis a novel, entitled "A Study of Psychological Conflicts as A Lesbian in Annie On My Mind Novel By Nancy Garden".

\section{Literature Review \\ 1.1 Definition of Psychological Conflict}


According to Jones in Astiningsih (2005:12), psychological conflict is a man struggling against himself, his conscience, his guilty, or simply trying to decide what he is going to do.

A conflict is a turning point during which an individual struggles to attain some psychological quality. Sometimes referred to as a psychosocial crisi, this can be a time of both vulnerability and strength, as the individual works towards success or failure. (Alwisol, 2010:134)

Based on the previous definition, the researcher concludes that psychological and behavioral conflicts are not in itself an indication of mental or psychological dysfunction. The psychological conflict is a conflict between man himself, his conscience, his guilt or simply tring to decide what he is going to do. Psychological conflicts are of central importance not only in neuroses, but also in psychosomatic disease, sexual deviation, and functional psychosis.

\subsection{Types of Psychological Conflict}

Davidoff in Batete (2007:20), there are types of psychological conflicts: approachapproach, avoidance-avoidance, and single and double approach-avoidance.

Approach-approach conflicts are occuring under two conditions: people are attracted about equally to goals. But, carrying out one goal means abandoning the other. Approachapproach conflicta are easier to resolve than any other type. As you tentatively near one goal, its attractiveness rises. As you emphasize the advantages, you are closer to your choice. At the same time, the appeal of the goal decrease and the conflict ends. People generally resolve approach-approach conflicts easily because they always result in something pleasant. Moreover, the alternatives can be achieved in turn. (2) Avoidance-avoidance conflict is when a person is simultaneously repelled by two goals (objects, actions, or whatever) and obliged to select one. (3) A single approachavoidance conflict is when person is attracted to and repelled by ne goal. A single option, in other words, has a bittersweet quality. (4) Double approach-avoidance conflicts have two goals, each with good and bad points. The only available job is dull but will provide income.

Real conflicts may not fit neatly into these categories because people often face more than two choices. Moreover, when examined closely, all options in a conflict have both positive and negative aspects. At the very least, the selection of any appealing option limits other choices; the adoption of any negative option has an attraction, removing the conflict and the anxiety it generated. In short, life conflicts are likely to be of the approach-avoidance type.

\section{Methods}

Research design used in this study is descriptive qualitative. A descriptive qualitative emphasizez the qualities of entities, processes, and meanings that are not experimentally examined or measured in terms of quantity, amount, intensity or frequency. (Denzin and Lincoln, 2000:8)

In this research, the researcher uses description qualitative because the researcher only discusses on psychological conflicts as a lesbian from Annie On My Mind Novel by Nancy Garden. 
Data and Sources of the Data

The data in this research is dialogues of characters and narration which derive from Annie On My Mind Novel by Nancia garden as the researcher's data source. The researcher also uses any description and deep explanation of words trough the novel being analyzed.

Data source that are used in this research comes from the novel entitled Annie On My Mind written by Nancia Garden Publisher: Farrar Straus \& Giroux (Juv); ISBN: $\quad 0-374404143$; Reissueedition (September 1992). For other sources are taken from some reference booka and some relevant data to support the analysis.

\section{Data Validity}

According Denzin (1970) there are four types of triangulation, they are : (a) Data triangulation, which entails gathering data through several sampling strategies, so that slices of data at different times and social situations, as well as on variety of people, are gathered. (b) Investigator triangulation, which refers to the use of more than one researcher in the field to gather and interpret data. (c) Theoritical triangulation, which refers to the use of more than one theoritical position in interpreting data. (d)Methodological triangulation, which refers to the use of more than one method for gathering data.

In this research, the researcher uses two of the types of triangulation, first is theoritical triangulation. Here, researcher use more than one theoritical position in interpreting and supporting the data in the research in order to make the data more valid and also it helps the researcher in better understanding while the researcher make sense of data and information. For the second, the researcher use investigator triangulation which means, the researcher use more than one researcher in the field to gather and interpret the data. And the researcher who act as an investigator or validator is a lecturer who expert in the field.

\subsection{Technic of Data Collection}

In the data collection, the researcher doing process of gathering the data needed in conducting the study. The steps are: 1) Read the whole of part of the novel carefully and repeatedly; 2) Discussing about psychological conflict with peer in order to avoid misunderstanding the content; 3 ) Folding the important pages which consists of the problem that will be analyzed in study; 4) Marking the important quotation of the novel as references for observation of the researcher; 5) Last, underlining and making a note for the main data that related to the problem which will be analyzed by using some theories, concepts, and approach.

\section{Data Analysis}

Based on the development of model of analysis data by Miles and Huberman (2014), the researcher describes the steps into five explanations. They are: 1) Data source, the researcher gets the data from the novel entitled Annie On My Mind Novel written Nancy Garden which published by Farrar Straus \& Giroux (Juv); ISBN: 0-374404143; Reissue edition (September 1992); 2) Data collection, the researcher doing process of gathering the data needed in conducting the study; 3 ) 
Data reduction, the researcher categorizes and classyfies the data into limitation of study. Not only that, the researcher also codes the data in order to make it easier in identification the data; 4) Data display, the researcher shows the main data which match with research problem, they are: psychological background of main character, psychological conflicts, and the overcome of psychological conflict of main character. The display will be describe in the form description from the comprehension of narrative, dialogues, and thinking of the author which is stated in narrative of Annie On My Mind novel by Nancy Garden; 5) Conclusion drawing, the researcher will verificate the data with recollect the data. Data verification is also mean to find another data which not suitable with data before. If the data same with the data before, the researcher can report the conclusion of the exact data in the study.

\section{Findings}

\section{Psychological Background of Liza Winthrop}

In this part, the researcher found some psychological background which described the personalities of Liza Winthrop as the main character in Annie On My Mind novel.

1) Introvert

Liza Winthrop had an introvert psychological background. It was showed by some actions that she did in every her problem or her daily life. Although in her school, Foster Academy, her position was as a student body president, she still really had no close friends. In data $1 \mathrm{~A} 1$, in the first line, there was sentence in novel that showed that Liza was an introvert person. The sentence was said by her mother. There, her mother tried to tell Liza that she was also have female close friend only when she was little younger than Liza.

Data : 1A1

"I know what it's like to have no close friends and then suddenly to have oneit happened to me, too, when I was little younger than you. Her name was June, and she was so beautiful I had remind myself not to stare at her sometimes. We loved each other very much, the way you and Annie do-maybe not quite so intensely or quite so-so exclusively, but very much. There was one night..."

(Page 106)

\section{2) Masculin}

Liza Winthrop was not feminine girl. Her appearance was more looked like boy than girl. In data 1B2, in the last line. showed that Liza was a girl with masculin appearance. When most of girls put conditioner on their hair in order to smooth their hair, Liza even never done it before. So, when her mother had made wear a dress and put conditioner on her hair, she felt that the things was not smell like herself.

\section{Data : 1B2}

Mom had made me wear a dress, and had tried to get my hair to stay in place by making me use conditioner, which I'd never done before, so I didn't even smell like myself, at least my hair didn't.

(Page 113) 
3) Responsible

Liza was a person with high responsibility. She was a person who will not run from her responsibilities. She would look for how to responsible for what she have to. In data $1 \mathrm{C} 1$, she realized that her main responsibility as a council president was to preside at meeting every week. She realized it although for the first time when she was nominated as a student council president, she was wishing that she was homesick in bed with flu, she still accepted the nomination and did the responsibility well.

Data : $1 \mathrm{C} 1$

As far as I was concerned, my main responsibility as council president was to presideat meetings every other week.

(Page 11)

\section{4) Idealist}

As a young girl and student, Liza was an idealist person. She did not like rules too much. She was also prefer to lived her life by her own ways and her own mind. She did not like bonded by rules, especially the rules which did not work enough wheather it was for good reason.

In data 1D3 in the last line, Mrs. Poindexter even directly said that she have admired Liza's idealism.

Data : 1D3

"Eliza," she said, "you are seventeen, aren't you?" I nodded. "Quite old enough to know right from wrongindeed, until now, you've shown a reasonable sense of morality, that stupid incident last fall notwithstanding. This may surprise you, but" -here she smiled ruefully-"I have even always felt a begrudging admiration for your stand on the reporting rule. Naturally,... in my position, I have not able to agrre with your stand, because experience has taught me that most young people are not to be trusted. I have admired your idealism, however. But now you-you..."

(Page 103)

\section{5) Kind Heart Person}

In data 1E2, in the third line, Annie showed Liza's heart. It was about how Liza really nice to others. No matter how hard Liza's condition and position, she always gave and tried her best to get what everyone's expects from her, especially as a student president.

Data : 1E2

"I know. You're student council president, but you're really just a person. Probably a pretty good one, but still just a person. Because you're student council president, everyone's expects you to be perfect, and that's hard. Trying to live up to everyone's expectations and being yourself, too-“"

(Page 33)

\subsubsection{Psychological Conflict that Liza Winthrop Got}

In Nancy Garden's novel, the researcher found that Liza Winthrop as the main character in the novel got some psychological conflict when she realized that she falled in love with Annie Kenyon. They were approach-approach conflict, double approach-avoidance conflict, avoidanceavoidance, and single approach-avoidance conflict. 
1) Approach-Approach Conflict

Approach-approach conflict occurs when people were attracted about equally to goals, but only took one goal which means other goal abandoned. The following excerpt of example.

In data $2 \mathrm{~A} 1$, from the first until the last line, Liza got her approach-approach conflict. It was occured when she was attracted about equally goals; Annie's kissing was wrong, bad, and sinful and Annie's kissing was so right, natural, true, and good.

Data : 2A1

"“I--I don't know," I said. It was like a war inside me; I couldn't even recognize all the sides. There was one that said, "No, this is wrong;you know it's wrong and bad and sinful," and there was another that said, "Nothing has ever felt so right and natural and true and good,"and another that said it was happening too fast, and another that justwanted to stop thinking altogether and fling my arms around Annie and hold her forever. There were other sides, too, but I couldn't sort them out. "Liza," Annie was saying, "Liza, I--I've wondered. I mean, Iwondered if this might be happening. Didn't you?" I shook my head. Butsomewhere inside I knew I had at least been confused.

(Page 51)

\section{2) Double Approach-Avoidance Conflict}

Double approach-avoidance conflict is when Liza was faced by two choices where in each option there was positive and negative things. The data which showed Liza's approachapproach conflict showed in data 2B2 from the first line until the last line. There, Liza got two choices. They were Liza told to her mother about the truth or Liza did not tell her mother about the truth. For the first choice, the positive thing that Liza got was if Liza told her mother what was going on in Ms. Stevenson's house, it would make her mother calmer because the information from Ms. Baxter and Mrs. Poindexter were not true at all. The negative thing of it, if Liza told her mother what was happened in Ms. Stevenson's house, it would make her mother know that Liza and Annie were a lesbian couple, not just a friend like her mother expected.

For the second choice, the positive thing if Liza did not tell to her mother about what was happened in Ms. Stevenson's house, it would make her mother not know about Liza's relationship with Annie. And it was good for her mother's psychology because her mother too expected and believed that Liza and Annie just a couple of close friend like other teenagers. So, her mother's heart would not break because of the truth. The negative thing for the second choice was if Liza did not tell to her mother about what was going on in Ms. Stevenson's house, it would make her mother in a big question because of Ms. Baxter and Mrs. Poindexter information. It would make Liza's mother kept asking about the truth of the information.

Data : 2B2

I couldn't help it; I knew I had to leave or blurt out angry words I'd be sorry for later. She was making it impossible, impossible for me to tell the truth. I wasn't sure I wanted to anyway, but how could I even think of it now? I wrenched myself away from her and ran into the bathroom,where I let the cold water flow till it was nearly ice, and 
splashed it on my face over and over again. I tried to think; I tried so hard to think--but there was only one word in my mind and that word was "Annie."

(Page 106)

\section{3) Avoidance-Avoidance Conflict}

A single approach-avoidance conflict is when people are atracted with the only choice, but they do not know what the choice is bad or good. Liza got this type psychological conflict at the first she met with Annie. It was showed in data $2 \mathrm{C} 1$ from the first until the last line.

Data : 2C1

She stood there silently, as if in awe of the screen, and then bowed her head. Two or three people coming in glanced at her curiously and I tried to tell myself it was ridiculous for me to feel uneasy. You could walk away, I remember thinking; you don't know this person at all. Maybe she's crazy.

Maybe she's some kind of religious fanatic.

(Page 5-6)

\section{4) Single Approach-Avoidance Conflict}

Avoidance-avoidance conflict is when people must choose two choices, but they do not want choose both of it. In data 2D1 from the first until the last line, when in the Trustees Board meeting, Liza got her turn which she was asked about her version of incident in Ms. Stevenson and Ms. Widmer's house. There she got two choices; honest or lie. At the time, she did not want to lie anymore, but also did not want to tell everything either.

Data : 2D1
Mr. Turner did smile then, and said, "Certainly, Mr. Winthrop, and I thank you for doing so with such economy. I shall try to use--er--plainer language."

Of course then I felt like a dummy, which didn't help at all. "Liza,"said the red-haired woman, "mostly we'd just like your version of whathappened when Ms. Baxter knocked at the door. Can you tell us?" I didn't know what to say at first, so I licked my lips and cleared my throat and did all the things people do when they're stalling for time. I didn'twant to lie any more, but I didn't want to tell them everything either.

(Page 117)

\subsubsection{The Way of Liza Winthrop \\ Overcomes her Psychological Conflict}

1) Liza's Overcome of ApproachApproach Conflict

In data $3 \mathrm{~A} 1$ from the first line until the last line, Liza overcomed her approach-approach conflict with abandoned the other of choice or goal. In data 2A1, Liza got two choice; first, Annie's kissing was wrong, bad, and sinful, second, Annie's kissing was so right, natural, true, and good. So, in data 3A1, Liza finally abandoned her first thought (Annie's kissing was wrong, bad, and sinful). She abandoned her first thought because when Annie said sorry about her confession that she might be a gay to Liza and she also said that she would go if what she said hurt Liza, there Liza told Annie that she loved Annie. Here, Liza chose her second thought about what they did and thought that was good, natural, and true.

Data : 3A1 
"No," I managed to say, "no--it's not anyone's fault." I know that underneath my numbness I felt it made sense about me, too, but I couldn't think about it, or concentrate on it, not then. Annie turned around and looked at me and the sadness in her eyes made me want to put my arms around her. "I'll go, Liza," she said, standing up. "I--I don't want to hurt you. I don't think you want this, so I have hurt you and,oh, God, Liza," she said, touching my face, "I don't want to, I--like you so much. I told you, you make me feel--real, more real than I've evert hought I could feel, more alive, you--you're better than a hundred Californias, but it's not only that, it's ..."

"Better than all those white birds?" I said around the ache that was in

my throat again."Because you're better than anything or anyone for me, too, Annie,better than--oh, I don't know-- better than what--better than everything--but that's not what I want to be saying--you--you're--Annie, I think I love you." I heard myself say it as if I were someone else, but the moment the words were out, I knew more than I'd ever known anything that they were true.

(Page 51)

2) Liza's Overcome of Double Approach-

\section{Avoidance Conflict}

In 2B2, when Liza's mom knew about what was going on in Ms. Stevenson and Ms. Widmer's house in Ms. Baxter's version, Liza wanted tell the truth to her mom, but she could not because her mother was too shock, so Liza thought it would be make her mother in worse condition. Finally, in data 3B2 from the first line untill the last line, she lied her mother to protect her mother's heart to overcomed her conflict.

Data : 3B2

When I went back into the living room, Mom was standing at the window looking out at the new leaves on the gingko tree outside the window."Look," she said, pointing to a small gray bird darting among thebranches. "I think she's building a nest." She turned to face me, and put her hands on my shoulders. "Liza," she said, looking into my eyes,"I want you to tell me the truth, not because I want to pry, but becauseI have to know. This could get very unpleasant--you know that. We can't fight it with lies, honey. Now--have you and Annie--done any more than theusual--experimenting is, I know, a bad word, but I think you know whatI mean. Has there been any more than that between you--more than what I told you was between me and June?" Her eyes were somber; there was fear in them, such fear and such pain, and such love as well, that--I'm not proud of it, I make no excuses--I lied to her. "No, Mom," I said,trying to look back at her calmly. "No, there hasn't."

(Page 106-105)

\section{3) Liza's Overcome of A Single Approach-Avoidance Conflict}

In data $3 \mathrm{C} 1$ from the first line until the last line, she overcomed her conflict was, at the time, without knowing Annie at all, she just joined with Annie in playing role in the musseum. When she thought that maybe Annie was a crazy person, she even 
did not walk away and just stayed there with Annie.

\section{Data : 3C1}

But I didn't walk away, and in a couple of seconds she turned, smiling. "I'm sorry," she said as we left the room, "if I embarrassed you."

"That's okay," I said. Even so, I led Annie fairly quickly to the Hall of Arms and Armor, which I usually go through on my way to the temple. The Hall is one of my favorite parts of the museum--one is greeted at its door by a life-sized procession of knights in full armor, on horse back. The first knight has his lance at the ready, pointed straight ahead,which means right at whoever walks in. Annie seemed to love it. I think that's one of the first things that made me decide I really did like her, even though she seemed a little strange.

(Page 6)

\section{4) Liza's Overcome of Avoidance- Avoidance Conflict}

When in the Trustees Board meeting, Liza got her turn which she was asked about her version of incident in Ms. Stevenson and Ms. Widmer's house. There she got two choices; honest or lie. At the time, she did not want to lie anymore,but also did not want to tell everything either.

In data 3D1 from the first line until the last line she just told what should she told without spoke it everything clearly to overcomed her avoidance-avoidance conflict.

Data : 3D1

But finally I realized she hadn't asked me about what had happened before Ms. Baxter arrived, so I relaxed a little. I told them that it had been more or less the way Ms. Baxter had said, except that she'd started to go upstairs before she'd seen Annie and that I didn't think I had "forcibly prevented" her from doing that, although I had tried to stop her. But the more I talked the more I realized it was obvious that I was leaving a lot out--and I also felt more and more that whatever I said wasn't going to make much difference anyway. It was what we were that Mrs. Poindexter and Ms. Baxter were against, as much as what we'd done. As soon as I realized that, I thought it was all over.

(Page 117)

\subsection{Discussion}

The finding from data analysis are put together into unit of discussion. All findings are based on the research problem in the research problems in Chapter 1, they are psychological background of Liza Winthrop, psychological conflict that Liza Winthrop got, and the way Liza Winthrop overcomes her psychological background.

The researcher found there are five of Liza's Winthrop character or psychological background that is formed based on her life environment. Those are introvert, masculin, high responsible, idealist, kind heart-person. Liza's psychological background or characters orpsychological conditions are formed by her life environment. Those character or psychological background influence Liza Winthrop in overcomes her psychological conflict. The finding of this research also found in Mafita's research (2010) which has the same topic; psychological conflict in the main character in novel. In that research, the main character has some characters or psychological 
background or psychological conditions which formed by the main character life experiences and also formed from the main character life environment.

Those findings above are related with Stanton (1965:17) which states that the use of character term itself in any English literature suggests two different definition, firstly as the characters of the story presented, and secondly as behavior, attraction, willing, emotion, and moral principal possessed by the characters. In literature, character is a verbal representation of human being as presented to us by authors through the depiction of actions, conversations, description, reactions, inner thought and reflections, and also through the author's own interpretative comentary. Characters are the life of literature: they are the objects of our curiousity and fascination, affection and dislike, admiration and condemnation. Indeed, so intense is our relationship with literary characters that they often cease to be simply 'objects' (Bennet and Royle 2004:60). Psychological conflict is a man struggling against himself, his conscience, his guilty, or simply trying to decide what he is going to do. Psychological conflict is one of kind of conflict in which an individual is struggling or fighting their own soul, mind, and other forces or impulses in their own selfness (Jones in Astiningsih 2005:12).

There are four types of psychological conflict: approach-approach, avoidanceavoidance, a single approach-avoidance, and double approach-avoidance conflict (Davidoff in Batete, 2007:20).

Based on two theories above, the researcher tries to analyze psychological conflict in Annie On My Mind novel by Nancy Garden. In this research, the researcher only analyzed psychological conflict that Liza Winthrop as the main character in the novel. Beside psychological background of Liza Winthrop as the main character in the novel, the researcher also found some excerpt that showed psychological conflict that Liza Winthrop got that stated by Davidoff (2007) such as approach-approach conflict, double approach-avoidance conflict, a single approach-avoidance, and avoidanceavoidance conflict.

In this research, researcher found there are two of psychological conflicts that Liza Winthrop often got. They are approachapproach conflict and double approachavoidance conflct. It is because from all her psychological conflict, approach-approach conflict and double approach-avoidance conflict are the most conflict that she have to faced when she falled in love with Annie Kenyon and that feelings came up the problems for Liza Winthrop as the main character.

Dafidoff (2007) told that approach-approach conflicts are occuring under two conditions: people are attracted about equally to goals. But, carrying out one goal means abandoning the other. Approach-approach conflicts are easier to resolve than any other type. As you tentatively near one goal, its attractiveness rises. As you emphasize the advantages, you are closer to your choice. At the same time, the appeal of the goal decrease and the conflict ends. People generally resolve approach-approach conflicts easily because they always result in something pleasant. Moreover, the alternatives can be achieved in turn.

Double approach-avoidance conflicts have two goals, each with good and bad points. 
The only available job is dull but will provide income (Dafidoff:2007).

Based on the analysis, the researcher found the way Liza Winthrop overcomes her psychological conflict influenced by her psychological background and also by Davidoff (2007) statement.

In this research, researcher found there are two of psychological conflicts that Liza Winthrop often got. They are approachapproach conflict and double approachavoidance conflct. It is because from all her psychological conflict, approach-approach conflict and double approach-avoidance conflict are the most conflict that she have to faced when she falled in love with Annie Kenyon and that feelings came up the problems for Liza Winthrop as the main character. But although it seemed difficult for Liza to face her psychological conflict at first, fortunately because she has psychological background as an idealist person who will live the life with her own ways and her own mind, she can overcome her psychological conflict well.

Dafidoff (2007) told that approach-approach conflicts are occuring under two conditions: people are attracted about equally to goals. But, carrying out one goal means abandoning the other. Approach-approach conflicts are easier to resolve than any other type. As you tentatively near one goal, its attractiveness rises. As you emphasize the advantages, you are closer to your choice. At the same time, the appeal of the goal decrease and the conflict ends. People generally resolve approach-approach conflicts easily because they always result in something pleasant. Moreover, the alternatives can be achieved in turn.
Double approach-avoidance conflicts have two goals, each with good and bad points. The only available job is dull but will provide income (Dafidoff:2007).

\section{Conclusions}

Based on the analysis, the researcher takes conclusions, first, there are five psychological conditions or background, they are: introvert, masculin, high responsible, idealist, and kind heart person. Second, there are two psychological conflicts that Liza Winthrop often got, they are approach-approach conflict where Liza faced two choices and choose one choice which means she abandone other choice and double approach-avoidance conflict which she have to face two things which each of the choice have negative and positive side. Third, the ways Liza overcomes her psychological conflict, mostly related with people who she loves. Liza did not think about herself enough, she just want other people happy, especially Annie, her lover, because when she knew that Annie more rotten than her, she decided to make Annie happy no matter what. She also cares about her family, that is why she does not tell the truth about her feelings with Annie because she does not want hurt her family. She sacrificies herself by covering the truth because she does not want harm her family and Annie, although finally she felt guilty so much about what was happen.

\section{Suggestion}

The resarcher gives some suggestions to others who are interested in this topic. First, for the student, the student can use this research as reference to analyze 
psychological analysis in other fiction. This research might be giving a new idea to some students to analyzed fiction or the students can use this research to analyze another aspect in the novel Annie On My Mind. Second, for the lecturer in English Literature Department, lecturer can use this research as example of analyzing a fiction, especially psychological conflict. The researcher also suggests to the lecturer to introduce another fiction. Last but not least, for the further researcher can analyzes such as social conflict. Figurative language, moral value, or other extrinsic aspects in Annie On My Mind novel. Besides that, the next researcher also can analyzes psychological conflict in other Nancy Garden novel like Prisoner of Vampires or Lark in the Morning where there are more psychological conflict can be found.

\section{References}

Alwisol. 2010. Psikologi Kepribadian. Edisi Revisi. Malang: UMM Press

Alawiyah, Mafita Rika Sari. 2013. Psychological Conflict as Reflected Katniss Everdeen Character in The Hunger Games Novel by Suzanne Collins. Malang: Kanjuruhan University of Malang

Astiningsih, Ratna 2005. A literary study on Social Conflict of Natnaniel Hawthore's. "The Scarlet Letter". Malang: Kanjuruhan University of Malang.

Arini, Kurnia Dyah. 2009. Penyimpangan Seksual Dalam Novel Suara Perih Perempuan : Lesbian dan Kawin Bule Karya Putri Kartini. Semarang: IKIP PGRI Semarang

Batete. 2007. Psychology 02: Psychological Conflict http://rpauryte.blogspot.com/2007/04/psychology-of-conflictssibling.html accessed on March 22th 2015, 05:00pm

Denzin. 1970. Triangulation http://www.strath.ac.uk/aer/materials/2designstrategiesineducationalresearch/u nit5/triangulation accessed on March 31th 2015, 08.56pm

Garden, Nancy. 1992. Annie On My Mind. Reissue Edition. USA: Farrar Straus \& Giroux (Juv)

Miles, Matthew B. Huberman, A.Michael. Saldana, Johnny. 2014. Qualitative Data Analysis A Methods Sourcebook. Third Edition. USA: SAGE Publication 